\title{
Reconstruction of Canadian National Identity: the Re-presentation of Canadian History in Margaret Atwood's Alias Grace and The Blind Assassin
}

\author{
Ziwei Yan \\ University of Science and Technology Beijing, Haidian District, Bejing, China
}

\section{Turbulent Canada in the 19th and 20th Century}

The 19th century witnessed the struggle of North American colonies to gain independence from Britain. The thirtheen British colonies of New England fought their Second War of Independence as the United States of America, and Canada, after years of political turmoil, became a single, self-governing confederation which proceeded to expand and eventually took over the entire northern half of the continent.

Canadians' thirst for independence was inevitably triggered by its neighbour. Even though the United States of America earned its independence through the Revolutionary War (1775-1786), the British Navy kept harassing American ships, intercepting their cargo and abducting American sailors, which threatened American sovereignty. Under such circumstances, the Americans started their Second War of Independence against England in 1812. However, because of their geographical location, Canadian colonies where British forces stationed were the most convenient targets for Americans' assault, and Canada thus was in the danger of being merged into American territory. After two years of heavy fighting, the Treaty of Ghent was signed to restore the pre-war status quo, which also ended American territorial threats to Canada. In the shadow of the increasingly powerful neighbour who once threatened to annex their homeland, and out of their own demand for a greater say in the colony's government, the Canadians, especially the middle class rising with the economic and population growth of the colony, embarked on a campaign of systematic rebellion against the British colonial rule. The rebellions of 1837 - critical events on the way to Canadian nationhood ("Rebellions", McIntosh) was led by William Lyon Mackenzie. The rebels, with a view to rallying against the authoritarian rule of the wealthy, British-born landowners, planned to march toward Toronto, the capital of Ontario and also the center of British dominance, however, they were subdued by loyalist troops in Montgomery's Tavern. After that, Mackenzie fled to the US and called for reform again, yet he and his followers were defeated by Canadian militia once again, and several rebels were even executed for treason. Nevertheless, the rebellions did result in a more democratic system and a unified entity for Canada. In 1841, Britain passed the Act of Union, merging Upper Canada-British Canada-and Lower CanadaFrench Canada - into a single colony, and introducing a joint parliament to Canada, in which the most popular political leaders from each community were appointed to run the colony for the British governors. Meanwhile, Britain's other maritime colonies yearning for democracy and better development went through similar political turmoil, and finally merged together to form the Dominion of Canada.

It was the Canadian politicians who pushed for the merge of all of Britain's remaining North American colonies into a unified, autonomous colonial confederation, and the British government, in order to avoid another "Revolutionary War", approved a draft constitution for the proposed confederation on July 1, 1867. A new mega-colony whose unified federal government was powerful enough to regulate matters of national importance such as trade and immigration was established, while the individual provinces retained dominance over local matters like education, housing etc.. Later, driven by the ambition of Canada's first prime minister John A. Macdonald (1815-1891), a giant trans-continental railroad, known as the Canadian Pacific Railway, was constructed to attract more immigration in the west and north of North America, which could be then absorbed into Canada to enlarge its territory.

Although Canada gained more control over its own national affairs and expanded its territory step by step, America's threat to Canada, or more precisely, the Canadians' sense of being threatened by America did not fade away. The United States fought a civil war from 1861 to 1865 over slavery, during which the British government once again interfered in America's national affairs by supporting the pro-slavery southern states which were eventually defeated in the war. Correspondingly, the Americans again saw the Canadian colonies as the possible breakthrough to completely get rid of the British rule. Besides, huge amounts of Irish immigrants arrived in Canada because of the Great Famine of the late 1840s. They had intended to immigrate to the US, yet stopped at the Canadian ports because of the cheaper passage, but they were not welcomed by the Canadians who resented them for many difficulties and cholera epidemics they brought to the land ("20th Century History", McCullough).

To conclude, Canada's national identity in the 19th century was in a disunited state. Facing the threat of the United States abroad, Canada expanded its territory at home whose sovereignty still belonged to Britain, and could not accept immigrants who would later become its member on account of the troubles brought by them. The sense of nationhood was not constructed yet, hence the Canadians' anxiety and self-doubt in this stage, which are fully presented by Margaret Atwood in her historical fiction Alias Grace.

The 20th century was an era of turbulence not only for Canada, but also for the whole world. Two world wars and the Great Depression were harsh tests to all countries, and Canada, after 
going through these ordeals, grew to be a prosperous, and legally independent nation.

Before World War I, Canada transformed from a nation of farmers, fishermen, loggers and fur traders into an industrial country in which new cities began to spring up. The Industrial Revolution stimulated employment in city-based factories and encouraged the Canadians to avail themselves of their raw natural resources which could be processed into serviceable products. The nation's prosperity attracted more and more immigrants to settle down, leading to its largest population boom which changes its ethnic makeup. However, the illusion that Canada had already become one of the most industrialized, modern and powerful nation was soon shattered by World War I, which Canada was forced to join due to its status as Britain's colony. Despite that the prime minister of the time, whose opinion represented that of the most Canadians, was willing to support Britain in the battlefield, he asked for a greater voice for Canada's government in organizing and commanding the Canadian army. In 1926, under the pressure of Canada and other self-governing white British colonies, Britain declared in an Imperial Conference that all the colonies were "equal in status" with Britain, which marked the formation of a "commonwealth". Later, in 1931, Canada was given the right to make laws by Britain through the Statute of Westminster.

Another test for Canada following World War I was a worldwide economic collapse known as the Great Depression, which bankrupted countless factories and caused steep declines in employment. In order to make a living, the desperate laborers were attracted by the communist idea of overthrowing the capitalist system and building a society where they can share wealth with the capitalists, namely, those factory owners. Violent labour unrest was suppressed, and the Canadian communist party was labeled as unlawful and disbanded by the government. At the end of the Great Depression, the Second World War broke out. Canada, after Britain declared war on Germany, willingly joined the war and fought under the Canadian command for the first time. As a result of the huge demand of ammunition, weapons and vehicles, the war greatly eased Canada's economic suffering, and even allowed Canada to become a world leader in industries like car-building and chemical processing.

In 1982, Canada's Prime Minister Pierre Trudeau's Constitution Act was approved by the British Parliament, which legally recognized Canada as a nation in its own right. The British Parliament surrendered its last power over the country, that is its control of Canadian constitutional law, to Canada ("20th Century History", McCullough).

On the surface, Canada grew stronger both economically and politically as an independent nation in the 20th century. The baptism of two World Wars and the Great Depression transformed Canada into a new world power. However, Canadians' way to obtain independence was more like British rulers devolving power to Canada's government, rather than through popular revolt against imperialists to gain their unique national identity. In addition, Canada still lived in the shadow of American economy and culture (as stated in chapter II) after it was legally independent, therefore, it is reasonable to infer that Canadians lacked national consciousness. Canada's "self" in this period was represented by the authorities, namely elite white men, who were used to having "their noses pressed to the windows, looking out" at their neighbours, and were overwhelmed by the Western powers. The schools they founded were "bastions of the British Empire". According to Atwood, they learned "the Kings of England and how to draw the Union Jack and sing Rule Britannia" (Second Words, 173), and felt kings and queens in British history were much more exciting than Canadian explorers. Likewise, the official history paid more attention to the American revolution, the French revolution, the Civil War and other stirring events which had taken place outside Canada, while depicted Canada as a colourless place without much historical conflict to speak of (Second Words, 174). The absence of marginalized groups-women, the working class and groups like the Communist Party that represented the interests of the working class-has left Canadian history lacking its unique experiences, creating the vacuum of the history. It explains why, according to Atwood, Canada was presented to them in their schools as colourless and dull (Second Words, 174). For this reason, Atwood deconstructs the authority of the official discourse through Alias Grace and The Blind Assassin, recalling the history in the 19th and 20th centuries to speak for those who had no voice, and further reflecting on the pale descriptions of Canada in the textbooks to reveal the Canadians' psychological state and their attitude toward national identity at that time. In this way, Atwood offers the Canadians another perspective to better understand their history and themselves, which contributes to the reconstruction of Canadian national identity. As Chen Points out, "[t]he precondition for looking forward is to look back, and facing the past is the only way to move ahead" (232). Atwood's historical fictions are not just concerned with the past, but also Canada's future.

\section{The Discovery of Canada's "Self" through the Internal "Other"}

\subsection{Canada in the 19th Century in Alias Grace}

\subsubsection{Revelation of Canadians' Garrison Mentality}

Based on the true story of the 19th century murderess Grace Marks, a handmaid who was accused, along with her so-called lover James McDermott, of murdering her employer Thomas Kinnear and his housekeeper Nancy Montgomery, Atwood restores the life of Grace as well as the era when she lived in the form of collage: she pieces together the newspaper clippings, the description of an early Canadian woman writer who visited Grace, the records of the Penitentiary where Grace was imprisoned, testimony of relevant persons in the court and Atwood's own imagination, which are sometimes contradictory. Instead of choosing one single version, Atwood presents various possibilities to readers. She gazes internally at the official historical records, denying the Canadians' status of being solidified and frozen by the unilateral gaze of the official history. By positively deconstructing the official discourse, Atwood allows herself to subjectively reconstruct Canada's history, especially that of the disadvantaged group - Canada's internal "other", and further to reconstruct Canadian national identity-Canada's "self". 
In the novel, Grace Marks is given her own voice to tell the story in the first person. For Grace, all reports concerning her are like a mirror, in which she can see "herself", no matter it is true or just an illusion of her own image. Rather than accepting the image reflected in the mirror, which is constructed by the authority, and therefore suspecting her own identity, Grace gazes back at the official discourse, making her own comments and expressing her own thoughts, through which she, or Atwood, reveals the "Garrison mentality" of the Canadians in the 19th century, and the underlying causes of this national psychology at that time.

The discourses about Grace are constructed by newspapers, the visitors of the asylum, the court, the guards, lawyers, as well as the doctor, and Grace deconstructed them by gazing back to regain her own subjectivity. She notices the eyes hidden in the dark which are fixed on her-those under the bonnets, and behind the slit cut in the door, even she can't see it, she knows it's there (26). The structure of the asylums in Canada reflects the idea of Jeremy Bentham's Panopticon, which provides the spectators with a panoramic open view of the prison to satisfy their voyeuristic lust (Zhang 215): doors with windows imply a sense of peeping... and the asylum looks like a zoo, in which the patients were objectified as animals locked up for the show... (Miron 94). But Grace reacts to the eyes peeping at her: "people coming on the pretence of some errand or other, but really to gawk and gape" (Atwood 270 ) because "a murderess is not an everyday thing" (63).

In addition to the practical gaze from the visitors, gaze exists in the form of discourses fraught with prejudices. The Governor's wife has a hobby of collecting crimes from newspapers and pastes them in the scrapbook, just like ladies who went to the scene to see the hanging of Grace's accomplice McDermott, who wanted "to stare, to breathe death in like fine perfume" (21). And Grace reads repeatedly what they put in about her, and comments that "a lot of it is lies...Was I really a paramour, is their chief concern..." (19). Even though the scrapbook presents Grace as spectacle, an object everyone can look at and examine, Grace is able to reverse the gaze projected on her by gazing back to make her responses. Similarly, she reverses the gaze of discourses about her by putting contradictory materials together to ask how she can be all of these different things at once-"an inhuman female demon, an innocent victim; blue eyes, green eyes; tall, not above the average height; a sullen disposition, a pliable nature; cunning and devious, little better than an idiot" (15). She knows that the newspaper journalists like to believe the worst, "for even upstanding and respectable people dearly love to read ill of others" (Atwood 268), which in Grace's opinion, explains why they twist around her words that should have been innocent enough, and interpret the perfectly normal look of McDermott as sullen doggedhess and reckless defiance (269). And in the courtroom, every word that comes out of her mouth is mistakenly written down, and judges will not listen, as, according to Grace, "they seem to know more about what happened to me than myself" (232). Grace's lawyer even warned her that she should not say what she can actually recall, but to say what must have happened (271), on which Grace comments that he is always more fond of listening to his own voice than to someone else's (273). The gaze, in whatever form-prying eyes behind the door, or obsession with the imagination about crime and violence instead of truth - reveals the public voyeurism at that time.

As what was mentioned above, the asylum offers the spectators a beneficial position where they can gaze at the patients, while they themselves will not be seen or heard, likewise, the discourses about Grace written down by judges and journalists to fulfill their own imagination are parallel with the spectators' gaze, since they are constructed only by one side, which Grace is unable to respond to and defend herself against. Such pattern of voyeurism reflects the "Garrison Mentality" put forward by the Canadian literary critic Northrop Frye (Zhang 215). According to him, the underlying cause beneath this mentality, is Canada's identity that fears Canada's empty landscape (Spergel 141). We cannot understand the word "landscape" literally, but also metaphorically, taking it to refer to Canada's historical depth and breadth. Considering Canada's situation at that time, it is no wonder that the Canadians had such anxiety over their country: as one of North American colonies of Britain, Canada could not even be called a nation in the 19th century. Many European immigrants came to Canada with their old colonial thinking. They could neither assimilate themselves into Canada's wild land which would become their home in the future, nor looked away, and such ambivalence lead to their strange gazing posture: concealing themselves in the small stronghold of human civilization which is solid and closed yet with a small window opened in the hiding place, peeped at the uncivilized and undeveloped outside without being discovered (Zhang 216). The governor's wife and ladies' infatuation with death and crime, the asylum's visitors who applied various excuses to "gawk and gape", newspaper's deliberate exaggeration andrespectable people's appetite for reading ill of others, all embody Canadians' "Garrison Mentality" in the 19th century.

Nevertheless, after a hundred years' development, the influence of such mentality still dominated the Canadians. In Atwood's memory, their history textbook in high school was a small blue book entitled Canada in The World Today, in which Canada was portrayed as dull and ghostless, "devoid of romantic interest and rhetorical excesses" (Second Words, 110), from which the Canadians' unease about their empty and dull land can be detected. By gazing back and deconstructing those official discouses, Grace exposes the Canadian's "Garrison Mentality": as representatives of civilization, they are fond of watching others' pain and problems. Except for their anxiety over the vacuum the nation suffers from, their fear of the oppressiveness of other nations (especially the United States) (Spergel 141) also nurtures Canadians' Garrison Mentality.

The 19th century was marked by technological progress brought by the Industrial revolution in the West, which facilitated its colonization of other countries. Against this backdrop, as Canada's increasingly powerful neighbour, the United States posed a threat to the independence Canada was fighting for. Even though America once was a British colony as Canada in the 19th century, it now intended to invade Canada in the name of liberating it. Spiritually, American image as a savior is reflected in the American doctor Simon Jordan. In the novel, Simon travels around Europe to find a cure for mental illness, and aspires to build a model Asylum. 
He eventually finds his first patient Grace in Canada. In order to bring back her memory of the crime, Simon observes, records and analyzes Grace, while Grace, a murderer and psychopath, is the object of the gaze. Consequently, doctor Jordan symbolizes the American-savior-image whitewashed with science and rationality, and Grace epitomizes Canada, which is in desperate need of salvation. Through such image-setting, Atwood highlights the fear of Canadians who are anxious about their own uncivilized and barren land in the face of American threat. Nevertheless, in the novel, Atwood also responds to such mentality through Grace, who refuses to be unilaterally gazed at and constructed by the American doctor. During their meetings, Grace turns Jordan into the object of her "scrutiny": "her eyes were unusually large...they were far from insane. Instead they were frankly assessing him. It was as if she were contemplating the subject of some unexplained experiment; as if it were he, and not she, who was under scrutiny" (Atwood 41).

Their visual battle also reflects the phrenology - a concept developed by the German physician Franz Joseph Gall in 1796 and was the nineteenth century's most popular and popularized "science" (Cooter 2) —of that age and its close relationship with colonial domination (Zhang 211). She conjectures that the doctor's intention is to measure her head, and see if he can tell from the bumps on her skull what sorts of criminals she is: swindlers or embezzlers or criminal lunatics or murders (Atwood 20). Based on phrenology, men are not equal in the eyes of the Lord, and the Lord bestowed greater physical and mental gifts on some more than others (Cooter 183). But the definition of "greater" depends on the construction of the Western powers, which manifests itself in the fact that the prisons and asylums in Canada are studied by an American doctor. In response, Grace reveals a fact that madness is impossible to be known through "seeing", because "a good portion of the women in the Asylum were no madder than the Queen of England" (Atwood 22). Some women's madness comes out of a bottle, and some are in there to escape from their husbands' violence.

What's more, Grace's mockery of science, or her gaze at the West, can also be discovered in her bond with an American peddler named Jeremiah, who "although looks like a Jew or a gypsy, Yankee from Massachusetts" (105). He invites Grace to come with him to be a medical clairvoyant, and trade in "mesmerism and magnetism, which is always a draw" (199). Mesmerism or magnetism, named by Franz Anton Mesmer, a German doctor, after he felt that he perceived a fluid flowing through the body of his woman patient whose flow was affected by his own will ("The Birth of Mesmerism"), was discredited as a reputable scientific procedure. But as Jeremiah revealed, it was widely practised by questionable showmen in the 1840s (Atwood 352). Even at the end of the story, the truth Doctor Jordan attempts to guide Grace to recollect is finally dug out from Grace's mouth when she is hypnotized by Jeremiah, or Doctor DuPont that he disguises himself as. The success of Grace and Jeremiah undermines Simon's scientific discourse, and further represents Atwood's attempt to shatter America's illusion to annex Canada through the so-called science.

Another point that should be highlighted is Jeremiah's identity as an American peddler. Contrary to doctor Jordan,
Jeremiah is treated the same as Grace, and even McDermott, also a servant in Mr. Kinnear's house as Grace is, dares to use such words as "a common rogue of a peddler" to insult him (149). Jeremiah and Grace are essentially the same: they all belong to the disadvantaged groups regardless of their different nationality, as Jeremiah reminds Grace that, "you are one of US" (107). He further blurs the boundary between "the superior America" and "the inferior Canada" by making it clear to Grace that

In many ways it is the same as here. There are rogues and scoundrels everywhere, but they use a different sort of language to excuse themselves; and there they pay a great lip service to democracy, just as here they rant on about the right order of society, and loyalty to the Queen; though the poor man is poor on every shore. (198)

Jeremiah undermines national differences, indicating that good and bad are constructed artificially, and that Canada is equal to America in every way. In this way, he disrupts homogeneous and essentialist constructions of national identity. By uniting Jeremiah as an American with Grace as a Canadian, Atwood, reveals to readers that it is only a matter of persprctives. America may not be "the other" if the Canadians do not regard them so, therefore, there is no need for them to confine themselves to the fear of America and stand still.

To sum up, Grace gazes back to expose the Canadians', especially the upper class's voyeurism in the 19th century, behind which their Garrison Mentality can be detected. Through Grace, Atwood gazes at the internal "other" to reflect on the Canadian 'self". She points out the Canadians' anxiety over the empty country and their fear of the aggressive America, which persists to this day. Instead of stopping here, Atwood further deconstructs the stereotypes of the Canadians and the Americans through Jeremiah. History tells us that there is no way to avoid America when we talk about Canada in the 19th century. And if Canada denies the existence of America, it denies its own past as well as itself, because as Memmi indicates, the being of the colonized is a series of negations, and if he accepts these negations, he admits that he is the negative opposition of the colonists. In this way, the total rejection of the colonists means denying himself (Chen 133). Atwood responds to the Canadians' belief in their void history, which is reflected in her high school textbook, by revealing the underlying causes of this psychology. Moreover, she provides the Canadians with an opportunity for self-reflection, based on which they are able to walk forward to reconstruct their national identity.

\subsubsection{Reconstruction of the history of the disadvantaged} groups through the image of quilt

The disadvantaged groups in Canada, mainly represented by women in the novel, has always been silenced and constructed by the Tories composed of aristocratic immigrants from Europe and elite white males who are trapped themselves in the in history. That's why Grace compares herself to a wooden doll in the hands of those magicians who throw their voice at fairs and shows, and she is shut up inside that doll, and her true voice can not get out (221). However, in Atwood's novel, Grace is given her own voice, and she is not only able to reconstruct her own history, but also that of the 
working class in the 19th century through the image of quilt. Atwood, therefore, gazes back at the Canadians' internal "other" and reconstruct the history of disadvantaged groups and make up for their missing voice in history. In this way, she reminds the Canadians that the official history constructed by people with biases may not be authentic, and further offers them a way to rediscover their past as well as their "self".

Grace recollects her past at the request of Doctor Jordan, but instead of being guided and pushed by him to tell her story, Grace actually takes control of their whole conversation. They always meet in the sewing room where Grace talks to Jordan while working on a new quilt. Before their meeting, Grace thinks about what she should tell him. She realizes that some of what he wants to know is jumbled in her mind, but she chooses to pick out this or that for him, just like looking for some bits of cloth to make a quilt pattern (267).

Quilting, as a traditional female social activity, through which the subordinated women could express themselves and exchange experience, has often featured in literary texts written in English as a motif that reflects female viewpoints and psychological conditions (Rogerson 13). Grace, the master of quilting, expresses herself through the patterns she sews. After she is released from the penitentiary, Grace accepts the proposal of Jamie Walsh, who once worked in Mr. Kinnear's house with her, and later appears in court as a witness to charge Grace regardless of his past adoration of her, and they establish a family together. Even though Grace knows well that "Log Cabin" quilt is a thing every woman should have before marriage, as it means home (98), she does not make one for herself, instead, she buys one of this design at a sale, from people "who'd failed and were moving West" (343). This in fact implies Grace's attitude toward her marriage and her view on this new life (Rogerson 17). Their marriage is an arranged match, about which Grace is in the dark, and she has to accept it, otherwise, she will have nowhere to go. Her husband's past betrayal leads to her worries about the stability of her new life, and the second-hand "Log Cabin" implies her lack of a sense of belonging. Furthermore, the quilt even contains Grace's whole life and her attitude towards her own past.

Despite that Grace refuses to sew the pattern of "Log Cabin", she does make a quilt for herself, on which she blend three clothes in as a part of the pattern: one is white, from the petticoat of Mary Whitney-Grace's best friend, her alias, and her alter ego; one is faded yellowish, from Grace's prison nightdress; and the third is a pale cotton, a pink and white floral, cut from Nancy's dress (Atwood 349). Through the making of the quilt Grace is finally able to reclaim her traumatic past, or that of all three women, as they are essentiallythe same-all belong to the dispossessed and diasporic female working class (Goldman 10). Her mother's death, her loss of home, as well as her uncertainty about her future render her wandering; similarly, Mary and Nancy who are abandoned by their lovers because of pregnancy, are also homeless. The quilt unites three women together, which not only reconstructs Grace's own past, but the collective experience of the underprivileged female group. In addition, by stitching together the three pieces of clothes, Grace creates a "nonchronological, spatial representation" of her life and of her self, entwined with the physical life of the other two women central to her life, and in this way the fact that subjectivity is textualized is highlighted (Michael 439). Mary and Nancy, as part of Grace's own past, are her internal "other", whom Grace gazes back at in order to rediscover and further reconstruct herself. A final reconciliation is reached among the three, which prefigures Canada's final reconciliation with its own history. In this way, Canada's "self" will be able to unite with its "other", so as to construct its own national identity.

Likewise, Atwood adapts the discourse of quilt for the discourse of the written text, therefore, the quilt finds a place as a metaphor for her process of constructing women's story, which also serves as a way for Atwood to gaze back at the official construction of women and to defend them. The fifteen parts of the novel are all named after quilt patterns, which implies that all stories are amalgams of different bits and pieces. She puts different and contradictory pieces from nineteenth-century literature in the epigraphs or even uses them as separate chapters, but among these clippings, the most important source text Atwood intends to deconstruct is Susanna Moodie's story of Grace Marks in her Life in the Clearings (1853). According to the author's afterword, Atwood first encounters Grace Marks in Moodie's work, whose version she accepted without doubt, while 26 years later, she came to realize that the past is made of paper, and it can be newspaper stories, eyewitness reports, gossip and rumor, opinion and contradiction, in which human biases are unavoidable (Atwood, "In Search” 1514).

Moodie's retelling of the murder is a third-hand account (350), whose authenticity is questionable: she is unclear about the location of Richmond Hill and inaccurate on names and dates; she calls several of the actors in this tragedy by names that are not their own...(134). Besides, Moodie has the culprits cutting Nancy's body up into quarters, which "surely was not done", as if it were true, "the newspapers would hardly have failed to mention a detail so sensational" (134). In short, her version comes out of somewhat imagination. Nevertheless, Moodie did see Grace in the Lunatic Asylum in Toronto, so her first-hand observations are generally trustworthy (Atwood 350). She reports Grace as "lighted up with the fire of insanity, and glowing with a hideous and fiend-like merriment" (126), but soon after the publication of her work, and just after the change of the Medical Superintendent of the asylum, Grace was appraised as sane enough and thus sent back to the penitentiary. As for the reason why Mrs. Moodie added her imagination of the murder and depicted a "shrieking, capering" (Atwood 350) Grace, history gives us an answer. Mrs. Moodie was one of the first settlers who immigrated from Britain to Canada, which was a British colony in the 19th century, and also a wild and unenlightened land from her Western perspective. Moodie's less of identification with her new nationality drives her to uglify everything she saw, therefore, her historical records of the early Canada are unreliable. Correspondingly, history should not be subject to the prejudice of their forefathers, and be written one-sidedly.

The Irish immigration wave and the Rebellion of 1837 not only constitute Canada's turbulent 19th century, but exert great influence on Grace's personal life and her treatment at the hands of the press (Atwood "In Search", 1514). Like many Irish people do, Grace sails for Canada in 1840 with her 
family to obtain free land and start a new life. As Grace recalls, the ship they travel on "brought logs of wood eastward from the Canada, and emigrants westward the other way", and both were viewed as cargo to be ferried (73). The choking and filthy air of the cabin breeds various diseases, one of which kills Grace's mother, and the Irish people who survive the difficult journey are still in trouble. People in Canada believe that the Irish who cause "Irish Question"-the collision between Irish Catholics and English Protestants - bring the insurrection to their land, disrupting the existing order of British rule in Canada: Grace's first employer, Mrs. Honey, makes it clear that if Grace were a Catholic, she could not hire her, because "the Catholics are superstitious and rebellious Papists who are ruining the country" (86). Canadians' hatred for the Irish peaks when Grace is under suspicion of murdering a Tory gentleman. The Tory newspapers depict Grace as an extremely cruel monster who lures her accomplice to murder. Meanwhile, the Rebellion led by William Lyon Mackenzie, who takes the part of the Scots and Irish, to strive against the English gentry causes another stir in Canada. The Tories, once again, unite with the British rulers to suppress the rebels. As Atwood points out, in 1843 when the murder took place, newspapers were still writing about the badness or contribution of William Lyon Mackenzie (Atwood "In Search", 1514), and "those which supported Mr. Mackenzie and his cause were the only ones to say a good word for Grace, and the others were all for hanging her, and William Lyon Mackenzie as well"' (Atwood Alias Grace, 280). The reason behind this is that, the Irish people's national consciousness is tied to their religious belief. British government deprives Catholics of their political, economic rights and educational opportunities to compel the Irish to convert to the Church of England, essentially treating Ireland as a colony, rather than part of the United Kingdom. In this sense, the Irish's adherence to their faith is in fact a reaction against British colonization. Canada, contrary to Ireland, is satisfied with the British rule, and considers the Irish rebellion as a betrayal, that's why most Canadians are for hanging William MacKenzie who takes the part of the poor Irish. It follows that the official construction of Grace's image is closely linked with the political movements of that time and with the Canadians' national consciousness. Their lack of national identity causes their unease about the state of the nation, hence their fear of foreign influence and lack of confidence in developing independently after breaking away from its colonizers. This explains why in Grace's memory which comes from a dealer, the Montgomery's Tavern is a place where "Mackenzie and his band of ragtags held their seditious meetings" (147). Most Canadians do not even realize that the Rebellion struggles for their own welfare, instead, they believe it is meant to threaten their national security, regardless of the fact that they have not had a nation.

After uncovering that the Canadian history is constructed by their ancestors whose national identity was not formed yet, and reconstructing it by gazing back at their internal "other", Atwood moves forward to provide the Canadians with another way to understand their past. As history can be constructed/reconstructed like a quilt, the way to look at the quilt is similar to the means of understanding history. Atwood, with the help of Grace, hints that there are two ways to look at the quilt/history: there is a quilt called "Attic Windows" which has a great many pieces, and if you look at it one way it is closed boxes, but when you look at it another way the boxes are open... and that is the same with all quilts, you can see them in two different ways, by looking at the dark pieces, or the light ones (113). Similarly, the Canadians can view their history in two different ways, both of which are presented in the novel.

The leader of the Rebellion of 1837, William Lyon Mackenzie, finally returned to Canada in 1849 after being granted a government pardon. In 1859, when the novel is set, Mackenzie was not seen as a traitor to Canada, but rather as the father of reforms (280). His failure paved the way for more moderate reformists who worked together to bring democratic reform and self-government to the newly united Canada ("Rebellions of 1837", Buckner). During the twenty years when Grace is imprisoned in the Kingston Penitentiary, there are always reformists including wardens, priests and doctors who organize "The Committee to Pardon Grace Marks" (329) to petition for her release. They strive to prove with modern science that Grace suffers from "latent insanity at the time of the murders" (51), instead of simply defining her as a murder or a madman. The petition becomes more frequent after the advent of a fully representational Parliament under the leadership of Canada's first prime minister John A. Macdonald (1815-1891). Eventually, Grace is pardoned after serving twenty-nine years of a life sentence. Given that Grace was once considered as the epitome of the Irish insurrection, or even the instigator of Maclenzie's Rebellion which disturbs the British rule in Canada, the hard-earned Grace's release witnesses Canada's transition from being ruled to self-government with the awakening of national consciousness. And Irish immigrants later proved to paly an important role in Canada's history, in that they helped Canada grow as a whole, both economically and socially. What's more, it aroused the Canadians' national consciousness, and accelerated the unity of colonies into a confederation, and helped them take their first step in developing into a nation. The construction as well as interpretation of history by the means of quilt pattern challenges conventional history in its implicit rejection of linearity and "monism", offering an alternative means of reconceptualizing history-as nonlinear and pluralist (Micheal 428). The Canadians, therefore, should not deny their own history, and denounces it as dull and flat. It is likely that they can fill the empty history from another perspective, as Atwood fills the supposed vacuum of Canadian history by reconstructing the past of the disadvantaged groups.

In a word, Atwood gazes back at Canada's internal "other" - the known history of Canada forgotten by the Canadians in which the marginal groups were silenced by elite white males - to reconstruct Canadian history, and reverse people's idea about its emptiness, thus further paves the way for the construction of Canada's "self". Atwood, aided by the character Grace, exposes 19th-centuryCanadians' voyeurism, and their underlying Garrison Mentality - the fear of the empty land and other oppressive countries, especially the United States. This mentality persist even to this day, results in the Canadians' denial of their own history. Besides, Atwood questions such words as "madness" imposed on the disadvantaged groups or even the whole Canada in relation to their powerful neighbour, by refuting the "reason" America represents. Furthermore, she encourages 
the Canadians to shake off the Garrison Mentality by revealing that there is no essential difference between these two countries. After that, by drawing on the image of quilt, Atwood reveals that history is constructed by people, therefore, it is bound to be subjective and biased. Therefore, she deconstructs the official history presented by her high school text, which is dull and ghostless, and reconstructs it from the perspective of the silenced marginal groups. She gives voice to Grace, allowing her to unfold her experience as part of the lower-class women before readers' eyes, and reveals that Grace's destiny is also closely related to Canadian history at that time. People's attitude toward Irish famine immigrants and the Rebellion of 1837 influences the press's discursive construction of her. And the Canadians' strong anti-Irish immigrants and anti-Rebellion sentiment implies Canada's unformed national identity. Atwood provides different ways to interpret history following her disclosure of the fact that Canadian history was recorded by a group of ancestors whose national identity has not yet taken shape. Similar to the quilt which can present two different patterns if seen in two different ways, Canadian history is also likely to present different faces if the Canadians can look at their history from different perspectives. In this way, they can achieve a reconciliation with their internal "other", and construct a new "self".

\subsection{Canada in the 20th Century in The Blind Assassin}

\subsubsection{The meaning of getting close to the unattainable history}

In The Blind Assassin, a 20th-century female image is also the major epitome of Canada's internal "other" as that in Alias Grace, and analogously, Atwood reconstructs Canada's history in the 20th century through the memoir of the female character Iris. However, the difference lies in that The Blind Assassin emphasizes more the unattainability of history, which is reflected in the unreliability of Iris's records of history, regardless of the popular idea that Atwood is supposed to give her female character the most powerful and incontrovertible voice to defend herself and her group. But even though Iris's memoir may not be authentic, Atwood still facilitates the construction of Iris's story, and helps her finish her memoir to leave it to her runaway granddaughter, to let her "reinvent herself" (440). This contradiction perhaps emphasizes more the importance of history, or the reconstruction of history, as it is crucial to the rediscovery of Canada's "self" and further to the reconstruction of Canada's national identity.

Iris, time and again, highlights the inauthenticity of her narrative. When she tells her family histories to the readers she does not expect, Iris makes it clear that she hears all from her nursemaid Reenie, whose narration varies in relation to Iris's age, and also in relation to how distracted she is at the time (Atwood Blind, 519), and she collects different fragments of her past to reconstruct it. What she wants is not realism, but things to be highly coloured, simple in outline, without ambiguity (519). She acknowledges that what she has set down is not the truth: "not because of what I've set down but because of what I've omitted" (395). Hence, the crucial pieces of information are found not in what is said and written down but among the many gaps and silences that represent the unspeakable. Iris, or Atwood, suggests the unreachability of history, as it exists in the gaps, in Lacan's "Real". For Lacan, the Real is what is expelled when a signifier becomes attached to some morsel of reality: it is the bit that the signifier fails to capture (Lionel 83). "The Real must exist in tension with the Symbolic and the Imaginary, for existence to be, there must also be a state of non-being, therefore, opposed to the other two which are in the field of recognition by means of a signifier, the Real remains imperceptible, unsymbolised, and out of discourse" (83).

The idea that history cannot be reached through language was expressed earlier in Atwood's The Handmaid's Tale. In the section of Historical Notes, professor Piexoto compares the past to great darkness filled with echos. "Voices may reach us from it; but what they say to us is imbued with the obscurity of the matrix out of which they come..." (161). History is in the matrix/womb where we cannot reach anymore. Once we enter the mirror stage, we embark on a life-long journey to misrecognize our "self" as "other", as the image in the mirror that provides an illusion of self and of mastery (Klages 81), hence the experience of loss in the world of language. Whereas history is in matrix, or in the Real, which is out of discourse, therefore it still enjoys completeness. We desire to regain the sense of totality which only exists in the mother's womb, or the Real, but meanwhile, we cannot exist out of the world of language, therefore, all we can do is to infinitely approach but never reach the state of totality. Time beats at every trace of the past with "its sharp invisible teeth" (Atwood 360) and leaves a void that is impossible to be filled, which also marks the sense of loss for people who try to remember.

However, despite the unattainability of history, it does "exist in the present tense in some form" (Chen 145). Iris writes down in her memoir that "When you're young, you think everything you do is disposable...You think you can get rid of things, and people too-leave them behind. You don't yet know about the habit they have, of coming back" (346). The past also reemerges in dreams, where time is frozen, and "you can never get away from where you've been" (346), and "the pain of the past, though subjectively erased from memory, always restricts the content and form of the present, and is readily returned to the present through nightmares" (Chen 145). The past in fact constructs us today, and decides what we might become, that's why Iris finally makes it clear that she writes about her life for her granddaughter Sabrina. She encourages her to reinvent herself at will: "since Laura is no longer who you thought she was, you're no longer who you think you are, either"; likewise, because her grandfather was an orphan, and as to who his own father was, "the sky's the limit", What Sabrina inherits from him is "the realm of infinite speculation" (440). Similar to the role history plays in inventing one's identity, history, or people's perception of history is critical to the construction of national identity (Shin dissertation). Atwood gazes back at the past to reconstruct Canada's history in the eventful 20th century, to rewrite the experience of the disadvantaged groups who lived in a sea of biases, to appeal to the Canadians to reflect on their blindness to what once happened in the country and further to reconstruct their national "self".

2.2.2 The Reconstruction of the 20th-century Canadian History by the Voiceless 
The Blind Assassin is a "novel-within-a-novel": one is Iris's first-person-narration memoir, and the other is a science fiction whose writer is not revealed until the end of the book. Both reflect on Canada's situation in the 20th century, no matter in a twisted or documentary form, through which Atwood appeals to the Canadians to reflect on their amnesia, and then to reconstruct their national "self" by recognizing and accepting Canada's unofficial and unorthodox history.

The act of writing a memoir itself is a way to look back at the past. Iris provides "realistic" details and historical "facts" about her forgotten, unofficial personal and family history as well as Canada's history (Staels 151). On the one hand, it is Iris' way to recollect her own past, while on the other hand, it can be taken as Atwood's criticism of the amnesia Canadians suffer from all the time.

Atwood's attitude is most evident in people's debate about a memorial about World War I, which is recorded by Iris in her memoir. Iris's father, the owner of a big button factory, and a veteran who lost one leg and one eye in the war, initiates a project to build a memorial in the town. His favored design is a statue of a weary solider, which is rejected by other people, as they think the statue is "too dejected-looking, and also too slovenly" (127). They want something more triumphant, like the Goddess of Victory in other towns, and they want "For Those Who Willingly Made the Supreme Sacrifice" to be written on the front. Iris's father, however, rebukes them for their forgetfulness:

...if they didn't watch out he'd go in for bare-naked realism all the way and the statue would be made of rotting body fragments, of which he had stepped on a good many in his day. As for the inscription, there was nothing willing about the sacrifice, as it had not been the intention of the dead to get themselves blown to Kingdom come. (127)

The brutality of war has already faded away from people's memory, instead, they only reamber the final triumph, see how the war stimulates their economy and contributes to the formation of the British commonwealth of Nations, which grants Canada self-government ("20th Century History", McCullough), therefore, they romanticize the war and admire sacrifices. But the truth is, the Canadian Parliament did not choose to go to war in 1914, and its later participation in the war was resultant from the fact that the country's foreign affairs were guided by London ("20th Century History", McCullough). All the casualties Iris's father sees in the battlefield, and the shattered faith which totures him all the time are resultant from Canada's position as a British colony. Consequently, he prefers to inscribe "Lest We Forget" on the memorial, because it "puts the onus where it should be: on our own forgetfulness", he says "a damn sight too many people had been a damn sight too forgetful" (127). The memorial is more for the living, rather than for the dead.

By means of Iris's father, Atwood implicitly criticizes not only the injustice of war, but the Canadians' amnesia. They forget Canada's original intention to join the war, and construct a system of discourse to deprive the dead of their own right to speak for themselves, and to excuse their forgetfulness. What the Canadians forget is not only what is mentioned above, and the whole memoir reveals what they have forgot—women's life experience and their contribution to the war, people's prejudice against the Communists, and their blindness to the war. The Canadians' amnesia persists to this day, which provokes Atwood into writing a "memoir" of Canada to tell Canadians how they come to be here. Meanwhile, "forgetting...is a crucial factor in the creation of a nation" (Renan 11), so Iris as the marginalized "other" becomes "the screen on to which dimensions of national amnesia deemed necessary in the biography of a nation or an individual are projected" (Howells 39).

\section{(1) Rewriting women's life experience with a "left-handed"} book

Even though the real thing will never sell, and most people prefer a past in which nothing smells, Canada's history "is never winsome, and clean" (48). Women's life experience against the cultural and social background of the 20thCentury-Canada is part of that unclean history, which should not be ignored. Iris is "the wife of the late Richard E. Griffen, the prominent industrialist and political figure", "the sister of noted local authoress Laura Chase," "the daughter of Captain Norval Chase who will be long remembered by this town", "granddaughter of Benjamin Chase, founder of Chase Industries", and "the sister-in-law of Winifred Griffen Prior, the Toronto philanthropist" (441), everything but herself. As the product of social construction, Iris "desires" what the "Other" desires - here "Other" refers to Lacan's big "Other", which means the field of etiquette, social rules, and manners (Žižek 58), but for Iris, "Other" is every kinsfolk mentioned above who titles her, and do what is expected of her.

As the eldest daughter, she has to bear the responsibility for her family, to save their factory by marrying a profit-minded capitalist; as an elder sister, she has always been asked to be a good sister to Laura by her mother, whose idea of her goodness "pinned onto her like a badge" (85), and as a wife, Iris is obliged to meet her husband's needs, to be moulded the way he wants her to look. All these social roles like "houses and steeples" encircling her where she sits in "the most central tower of them all" (355). She wears the clothes which "belong on someone else" (32), and her body is "like sand and snow-written on, rewritten, smoothed over" (324). She is constructed to be the projections of others' desire, while she herself has no idea about what she wants. She rejects Laura's suggestion that they can find a job to get away from the "steeple" her husband Richard builds to incarcerate them, as she creates an illusion that she wants to marry him, or at least she can accept him sooner or later (209). Her mis-recognized desire renders her blind to her own situation, and prepares her for being constructed according to "Other"'s expectations.

Nevertheless, Iris finally realizes her mis-recognition through her memoir. She gets rid of her blindness and gazes back at the past to find that she is "a round O, the zero at the bone" (355). Even though zero is a hole, an empty space, and a sphere of nothingness, it can be transmuted into being through naming (272), it is constructed according to others' will, and its essence cannot be revealed and expressed. Iris exists under the name of her husband, sister, father, grandfather and sister-in-law, while essentially she has no heart any more: "it had been scooped neatly out of me like the yolk from a 
hard-boiled egg, leaving the rest of me bloodless and congealed and hollow" (386). If we interpret the void created by this in Lacan's terms, it perhaps represents a kind of "lack".

According to Lacan, "lack" is always related to desire. When a subject makes a demand, it signals a need - a lack of something, therefore, he/she expects to receive from the "other" the precise thing he/she demands to fulfil this lack. However, what is demanded is never what is actually needed, and it is in this space between need and demand that desire appears (Bailly 92). In other words, the articulation of need must pass through the narrow gateway of language and what cannot squeeze through it and is left behind constitutes desire (Bailly 92). Accordingly, even our unconscious desire is organized by the linguistic system that Lacan terms the Symbolic Order or the big "Other" (Dino "Modules on Lacan"), which means that our desire is never our own, but a misrecognition of fullness where "there is really nothing but a screen for our own narcissistic projections" (Dino "Modules on Lacan"). To persist desire, lack is the crucial factor, as the distance from our object of desire keeps our fantasy alive, which does not correspond to anything in the real. Iris in her 80s grasps that the desires she once had were actually organized by the "Other", or "others" who weave her network of social relations, while her own desire is unreachable because language fails to express what she lacks (Lionel 172). The great lack hollows her heart out, and turns her into a "round O". That's why, according to Iris's memoir, sometimes she looks in the mirror to examine her face, but only to see herself "erased, featureless, like an oval of used soap, or the moon on the wane" (208).

What's more, we can get some profound massage from such moments when Iris sees "an older woman who might look like the grandmother I never knew, or like my own mother, if she'd managed to reach this age. But sometimes I see instead the young girl's face I once spent so much time rearranging and deploring, drowned and floating just beneath my present face" (40). The overlapped image in the mirror suggests that in Old Iris's view, the three women-Iris, her mother and her grandmother - become one at last, because they all share the same destiny: a voiceless victim of their family, or even the society. Iris's grandmother Adelia is from an established family which is halfway down the slippery slope because of risky speculations (54), that's why she has to marry money in order to rescue her family from declining. Grandfather was forty by then, intending to get his money's worth, therefore, he married Adelia for her good taste. Adelia christens their mansion "Avilion", the same place where King Arthur went to die. Iris surmises that "surely Adelia's choice of name signifies how hopelessly in exile she considered herself to be" (56). Adelia's obsolete Victorian style collides with the rise of capitalism driven by the Industrial Revolution in the 20th-century Canada, which reduces her to a voiceless decoration for the house. Avilion serves as the container of Adelia's desire, so it is marked by lack, the great gaping hole that cannot be filled.

The lack does not disappear after Iris's mother Liliana marries into the family, on the contrary, she intensifies this lack. Even though she marries Iris's father for love, World War I soon separates them and turns them into strangers to each other. Traumatized by the war, Iris's father becomes "a shattered wreck, as witness the shouts in the dark, the nightmares, the sudden fits of rage" (69), while her mother ruins her health due to her hard work to "do something useful for the war effort" during the war (65). However, Iris's mother is the one who makes further sacrifices. She is obliged to forgive her husband for visiting prostitutes no matter in military camps or in other towns after he comes home from war, to understand his morbid need under the circumstances (69). And her poor health does not prevent Iris's father from impregnating her again and again in order to obtain a male heir for the family factory, which ultimately kills her. Despite what she has to put up with, "not one word of complaint was ever heard to cross her lips", which is "entirely as it should be" (71). Both Iris's parents are victims of the times, of the war, but her father is allowed to vent out his anger, frustration and pain, whereas her mother is the one who must grin and bear it. Nevertheless, "there's often more in silences than in what is actually said" (71). What cannot squeeze through the gateway of language is probably her desire for a sense of belonging, and the great lack between what she really needs and what she can make a demand for renders Avilion empty and herself homeless.

The sacrifices men make to their country during World War I are acknowledged and even trumpeted through memorials, yet women's sacrifices are ignored and forgotten. Liliana, who is actually the epitome of women during the wartime, exerts herself the same as what men do in the battlefield. She organizes a Comfort Circle, which collects money through rummage sales to exchange for small boxes containing tobacco and candies, which will be sent off to the trenches. And her group spends half a day each week knitting washcloths, scarves and balaclavas and gloves for the troops in the drawing room. Soon, she gathers another battalion of women from south of the Jogues, who are older, less literate yet proficient in knitting, to make baby garments for the Armenians and overseas refugees. Always associated with "the second sex", embroidery is often dismissed as indecent and valueless (Parker 5), so is the domestic sphere it belongs to. However, after gazing back at the forgotten history, Iris proves that women's sacrifices are indispensable for the final victory of the war. In addition, Liliana visits maimed soldiers in the hospitals regardless of her own bad physical conditions. Meanwhile, she takes over the running of the factories, therefore, she has to meet daily with the male secretary and with the various factory foremen. Although juggling her group activities and factory business, Liliana is able to keep things running smoothly enough. She transgresses the constraints of femininity the art of embroidery imposes on women, and sets foot in the traditional male domain to demonstrate that all work is gender equal. Women should not be ignored and forgotten, instead, they deserve leave their own marks in the official history.

Apart from perceiving that her desire was the desire of the "Other" while she was "the zero at the bone", and that the three women - her grandmother Adelia, her mother Liliana and her-are the voiceless victims of the time, Iris reconstructs her "self" by effecting a reconciliation with her younger sister Laura, her "other" in the mirror stage. According to Lacan, during the mirror stage, "while identifying itself in the mirror, the child also identifies with something from which it is separated: it is as an 'other' that the Subject identities and experiences itself first" (Lionel 33). 
Therefore, the existence of the "other", or the mirror image which is mistaken by the child as its unified "self", marks the fragmented identity. The competition between "the visual gestalt" of its own body and the experience of fragmentation results in the child's aggressive tendency (Gounelas 692) to fight against its mirror image.

As for Iris, Laura is her mirror image, the "other" Iris once struggled against to "realize her sense of herself as an agent" (Hegel 114). When Iris stares into Laura's photo, she feels like peering into a well or pool, from which she can see her own reflection (Atwood 461), and likewise, seeing Laura from behind gives her a peculiar sensation: as if "I were watching myself" (340). The tension between Iris's "self" and her "other" Laura most clearly manifests itself in their rivalry for Alex Thomas, a communist who is hunted by the Police. Iris' knowledge that Laura loves Alex does not prevent her from becoming his lover, instead, out of mad jealousy and in order to shatter Laura's illusion that she "takes the pain and suffering onto" (417) herself to save Alex, therefore he will come back for her eventually, she reveals her secret relationship with Alex to Laura, which amounts to pushing her off the cliff and leads to her suicide. Lacan views jealousy in pre-verbal infants, for example, sibling rivalry, as another indication of how the child's experience of selfhood is bound up with the presence of others (CriticaLink "The Mirror"). Iris's desire for Alex, to some degree, is her desire for "the object of the other's desire". At their first meeting, it is Laura who soon finds that she and Alex are like-minded friends, while Iris considers him as a womanizer. But later, Iris manages to join their conversation because she thinks "he is talking mostly to Laura" and she "wants his attention" (165). The rivalry between the sisters for Alex, therefore, can be understood as "a deadly division of each within and against herself” (Gounelas 693).

Laura's death eventually sensitizes Iris to her blindness to the truth, and to Laura's significance for the construction of her identity, which triggers her to write a science fiction hinting at the real world under the name of Laura. No longer taking Laura as the object of her aggressivity, Iris recognizes her role as a collaborator - in the spiritual sense-in her own life (439), and they two actually exist as a unified one. That also explains why she signs the science fiction with Laura's name. "Laura was my left hand, and I was hers. We wrote the book together. It's a left-handed book. That's why one of us is always out of sight, whichever way you look at it" (439). This can also be seen in the photo of the three at the button factory picnic. Laura makes two prints of it, and cuts one of them out of each photo, with only one hand of the other remains because "she couldn't have got rid of this hand without making a wobbly margin" (194). Even though the photograph is torn, taking us back to "that moment of aggressivity in front of the mirror" (697), the inevitable presence of another hand indicates that, in Lacan's terms, the "self" cannot exist without its mirror image, without the "other". It is because of the symbiotic relationship between Iris and Laura, which is just the same as that between the subject and his/her mirror image, that one of them is always out of sight, whichever way we look at it (439).

According to Iris, this is a "left-handed book", which reflects Atwood's idea of literary creation. Sometimes it seems to Iris that it is only her hand, not the rest of her, that writes, that her hand has taken on a life of its own even if severed from the rest of her (325). This "bodiless hand" can be found in the photos as well: "In the lower left corner there's a hand, scissored off at the wrist, resting on the grass. It's the hand of the other one, the one who is always in the picture whether seen or not. The hand that will set things down" (441). The hand that is able to write transcends its nature as an organ of the body with the magic of being uncontrollable (Zhang 255), and this magic comes from the idea that, for writers, "there are two of him sharing the same body" (32), which is elaborated on by Atwood in her literary criticism Negotiating with the Dead. Atwood uses "dexter and sinister" instead of "right and left" to refer to the two hands, suggesting the link between "luck" and the right hand, hence the acceptance from the society, and that between "evil" and left hand, hence the disdain and rejection from the orthodox ideas of society (Zhang 256). Consequently, it can be said that writers' right hand belongs to their body, so they are controlled by their consciousness, while their left hand is manipulated by the "other", the evil twin sharing the same body with them. However, Iris acknowledges that both Laura and herself use their left hands to co-write the science fiction, which "retains its aura of brimstone and taboo even after fifty years since its publication" (Atwood 36). This indicates Atwood's attempt to unite the "self" and the "other".

She uses the example of Peter Schlemihl to illustrates her idea that each of them is "parasitic upon the other": Peter Schlemihl sells his shadow to the Devil and then realizes that without it he no longer has a valid existence (32). Laura and Iris blend together to form a unified "self" and write their shared past with left hands. What's more, for Atwood, the left hand is a metaphor for writers' alternative writing which challenges the traditional ideas of the society and themselves. Historically, male writing has always been the mainstream, whereas female writing was excluded. The fact that the word "history" can be disassembled into "his story" possibly implies that the history of humankind has long been written and constructed by men, thus it represents the male perspective. Under such circumstances, Atwood advocates writing with left hand in order to supplement men's right-handed writing with different voices from women's left-handed writing. The materials Iris writes down "really offer no definitive interpretation of her family's or the nation's history but, rather, a destabilization of the truth claims of historical writing in a postmodern context, in which different stories about the past are told from different perspectives" (Howells 63). The history of disadvantaged groups is told by Iris/Atwood from the female perspective, challenging the official records and the stereotypes constructed by these discourses. In addition to women's story, Atwood also reconstructs the history of other marginal groups, such as the working class and the communists during the Great Depression, and correspondingly, the capitalists' greed as well as people's prejudices are exposed. Only by recognizing and accepting Canada's unofficial and unorthodox history, the Canadians will be able to get rid of their colonial mentality and reconstruct their national identity.

(2) Reexamining the distorted records of the working class and communists 
The Great Depression witnesses how the working class and the communists are constructed by the capitalist class who has the right to speak. In response to the reduced demand caused by the economic downturn, many factory owners shut down their factories and banked their money to stem capital loss, which led to mass unemployment, and strikes by workers who struggled to survive. The Communist Party of Canada played a significant role in this national upsurge of struggle. However, their intention was vilified as "threatening world order and the peaceful conduct of international commerce" and "overthrowing the government" (Atwood The Blind, 312). The righteous labor union movements were defamed as the violence of bandits: these ruthless Bolsheviks and union organizers...set bombs and creep in at night and slit people's throats... they wanted free love, and the destruction of the family, and the deaths by firing squad of anyone who had money (178). The laborers, whose right to work was deprived of by the capitalists, were depicted to be "idle from inclination" (100), therefore, their did not deserve any smpathy. However, those workers and communists were deprived of their right to speak, and the capitalists' construction of them became the only official history of this period for future generations. To reverse such a situation and speak for these disadvantaged groups, Atwood creates Alex Thomas to rewrite history from their perspective. As a communist, Alex's ambition once was to

go in at the ground level, the level of starvation pay and bread and dripping and slag-faced penny-ante whores and boots in the face and puke in the gutter, to expose the workings of the system, the machinery, the way it keeps you alive just so long as you've got some kick left in you, how it uses you up, turns you into a cog or a souse, crushes your face into the muck one way or another. (245)

He stands for the lower class: the laborers, the prostitutes, and even criminals, whose voices are always forgotten and repressed by the official history. The history of Canada in the 1940s is written through the lens of social and political power, namely, the Liberal Party who represents the interests of the monopolistic bourgeoisie. And the capitalists, according to Karl Marx, whose ownership of an object denies its benefits to another, are enriched and empowered by the oppressed workers' efforts. Therefore, Alex's fight for the rights and interest of these marginal groups in itself harms the interests of the capitalists, and that's why his lofty goals are twisted as malicious destruction of the social order: the police firmly believe that it is he who sets fire to a factory and kills a loyal employee, which forces him to live under assumed names to escape from the manhunt.

The marginal groups, represented by Alex, and the capitalists represented by Richard E. Griffen, also have different accounts of war, from which we can see that the official history is unable to tell the whole story. Alex sees the suffering of endless mothers, limp children, bewildered old men, as well as raped women, raped men, and raped children (408), on the contrary, Richard celebrates the coming of war, as "it will pep things up - put paid to the Depression", and he cheers for the Munich Accord, because it "would usher in a new 'golden era' of peace and prosperity" (391). The capitalists once turned a blind eye to Germans' brutal violations of democracy, but they are keen to defend it during World War II, and the communists are no longer their enemies, instead, Joseph Stalin becomes everybody's loveable uncle (411). However, in essence, what they are hoping is that "Uncle Joe and Adolf will tear each other to pieces and get rid of the Jews for them into the bargain, while they sit on their bums and make money" (396). The papers give different accounts of war, just like the shifting attitudes of the capitalists toward the communists, which depend on whether what they do are good or harmful for their interests. The war takes on different appearances to different people: it takes place in black and white for those on the sidelines, and for those who are actually in it there are many colors, but for the others the war is like a newsreel, everything happens elsewhere (397). Accordingly, the records of war should vary in accordance with different voices from both the mainstream and the marginal groups.

To sum up, even though true history cannot be attained through language, Atwood still makes efforts to rewrite history, as it constructs the Canadians today, and decides what they will become in the future. By gazing back to question the official discourse, Atwood, with a "left-handed" book, reconstructs the past of disadvantaged groups-Canada's internal "other" including women, whose contribution to wars is ignored and forgotten, the working class and the communists, who are the victims of the capitalists' biases - during two world wars and the Great Depression, through which she criticizes the amnesia the Canadians suffer from, and their blindness to what once happened in the country. By calling for the Canadians' reflection on their past, and filling the gap of the history which was generally accepted by them, Atwood provides another possibility for the Canadians to reexamine themselves, and further to reconstruct their national "self".

(3) The intertextuality between the science fiction and Iris's memoir

Events and characters in Iris's account of Canada's history in the 20th century as revealed in the memoir are mirrored in the embedded science fiction story about the blind assassin and the sacrificial maiden (Staels 152), and in doing so, Atwood subtly reinforces her critical reflection on Canada's past.

The experience of the underprivileged groups, such as women and the working class, who appear in the guise of slaves in the science fiction, is similar to that in the real world. The Snilfards who are the aristocrats of Sakiel-Norn - the fictional alien city on the planet Zycron created by Alex to his lover-believe the proper sacrifices offered to the gods bring wealth to their city (27). Every year they offer nine girls born from the noblest Snilfard families, but soon these families take to adopting foundlings - the offspring of female slaves and their masters, and use them to replace their daughters (28). In order to make sure the sacrificial rituals go on smoothly, the girls' tongues will be cut out three months before they are due to be sacrificed (29). These mute girls are analogous to Iris and the other women in her memoir who share the same destiny with her. In addition to being silenced and unable to speak for themselves, women are objectified as commodities to be exchanged for the good of those noble families. Iris marries Richard to trade her youth for the revival of the family 
factory, as has been agreed by her father and husband; likewise, Adelia marries Iris's grandfather to save her family from declining.

What's more, as mentioned above, the sacrificial girls the daughters of slaves, from which we can see the class issue. Sakiel-Norn is renowned for its handicrafts, especially the carpets woven by slaves who are invariably children. The incessant close labour demanded of these children cause them to go blind by the age of eight or nine, and their blindness becomes the measure by which the carpet-sellers extol their merchandise: the more children blind for weaving one carpet, the higher its price. These blind children are then sold off to brothel-keepers to be exploited further. Those who escape take up the profession of cutting throats in the dark, and are hired as assassins (23). Nevertheless, although slaves are the means by which Sakiel-Norn achieves its magnificence and power, their value is totally denied by Snilfards, who claim that their riches depend not on the slaves, but on their own virtues and right thinking (27). The relationship between Snilfards and slaves "mirrors the realistic account in the memoir of the class-divided society in Canada of the thirties, the tension between the authoritarian government, the capitalist employers and the unemployed mob" (Staels 153). In the capitalist society there is the division between the bourgeoisie, the owners of the means of production, and the proletariat, "a class of laborers who live only so long as they find work... these laborers, who must sell themselves piecemeal, are a commodity" (Marx and Engels 83). Capitalists are like the Snilfards who accumulate their capital by extracting the surplus value by paying the workers less than the value of their labour, while the working class, or the "unemployed mob", are in the same situation with the slaves. Not only are they exploited by the capitalists in the factories, and then abandoned during the Great Depression, they are also humiliated by Richard as "idle from inclination" (100).

However, as the story goes on, a blind assassin saves a sacrificial girl and they manage to escape from Sakiel-Norn, which implies the solidarity which can be formed between the disadvantaged groups. The alliance is not confined to the lower classes, instead, the sudden invasion of the Lizard Men unites the whole society. Barbarians and urbanites, incumbents and rebels, masters and slaves all forget their differences and engage in a common cause (348). The Lizard Men actually symbolize the colonists, or more precisely, Hitler and Germans, given the international situation in the 1930s. Their plan to capture a large number of Earth women and breed a super-race, half-human, half-Xenorian Lizard Man (306) is another version of Hitler's Lebensborn project, which aimed to create a "super-race" or the "racially pure" Germanic/Nordic population ("The 'Lebensborn' program"). The science fiction not only mirrors Canada's civil unrest and the international turmoil in the 20th century, but offers a prospect of its future, or the message that Atwood intends to convey to the Canadians, through which a promising future is able to be achieved.

Canada never escapes from the threat of being colonized not only in the 1930s, when the British Parliament did not surrender its control of Canadian constitutional law over the country to Canada, but in the 21st century, when Canada's neighbour America rises as a great power, thus poses a threat.
Even though Canada already develops to be an economic and political power, it is unable to cope with such a threat calmly and properly. Psychologically, the Canadians still desire to "listen in on the neighbors with their ears pressed to the wall" (Atwood Second Words, 177). As desire and anxiety are complementary: anxiety is a way of sustaining desire when the object is missing, and conversely, desire is a remedy for anxiety, something easier to bear than anxiety itself (Evans 11), the Canadians' desire to look outside actually conceals their anxiety over their own land, which results in the boredom and lack of events in their history textbook. In order to ease Canadians' anxiety, Atwood digs deep into Canada's history to discover different voices, and attempts to offer a full picture of the past. The reconstruction of the history from the perspectives of the disadvantaged groups can also be understood as Atwood's intention to unite different groups, just like the dissolution of class barriers she depicts in the science fiction. It is probably the best way for the Canadians to get over their colonial mentality and to cope with the threat of being colonized. No longer do the Canadians merely hear the voice of the majority and the privileged class, and read the official discourse, they are allowed access to the voices of the underprivileged, to unite with their internal "other". The whole picture of the national history will render the Canadians acquainted with their own past, provide them with clear knowledge of their "self", and in this way help them reconstruct their national identity to arm themselves against external threats.

The science fiction is written by Iris after she comes to realize that Laura was seduced by Richard while she turned a blind eye to everything that was going on, therefore, this book is a way for Iris to gaze back at the past and to reflect on herself. To protect herself from the cruel reality, Iris would rather "waft around in the rarefied air" (268) as Richard suggested to her, to enjoy another kind of freedom, namely, "freedom from" (Atwood The Handmaid, 26), as there is the illusion that "only the blind are free" (Atwood The Blind, 23). To compensate for her blindness, Iris "co-writes" the science fiction - a "left-handed" book — with dead Laura. The literary writing, as illustrated by Atwood, is a process of trading with the dead, whose desire to be heard is satisfied by writers to exchange for their access to the past. "They want to be recounted. They don't want to be voiceless; they don't want to be pushed aside, obliterated. They want us to know" (82), such cry of the dead can also be heard in the novel: "Remember me. To you from failing hands we throw" (435). The dead control the past, the stories, and also certain kinds of truth (Atwood Negotiating, 88), therefore, nothing is more dangerous than to ignore them (Atwood The Blind, 435). By going from now to once upon a time, going from here to there, and descending to where the stories are kept (Atwood Negotiating, 88), writers bring back the treasure of the dead into the land of the living, and make the past available to all. Iris negotiates with Laura and brings back her story, through which Laura's demand to be heard is fulfilled, and what's more, Iris gets over her blindness and faces up to the truth. As for Atwood, she makes efforts to cure the Canadians' amnesia and blindness by negotiating with the dead, thus giving the Canadian readers access to their stories and proving that "the ancestors, ghosts and skeletons really are there" and as a culture they are not "as flat and lacking in resonance" as they were led to believe (Atwood Second Words, 110). 


\section{Conclusion}

To conclude, Margaret Atwood emphasizes once again the role history plays in rediscovering Canada's "self" and further reconstructing Canadian national identity through The Blind Assassin. Even though the book is a "novel-within-a-novel" - one is Iris's first-person-narration memoir, and the other is a science fiction written by Iris yet signed in Laura's name, they both reflect Canada's history in the 20th century, no matter in a twisted or a documentary way. The points here are that instead of following blindly the official version of history, Atwood gazes back at the past of the disadvantaged groups, Canada' internal "other", who are forgotten and ignored by the official discourse, to reconstruct Canada's history from their perspectives. These groups include women, whose contribution during the wartime is neglected, and the working class and the communists, who are the victims of the capitalists' biases. Atwood's efforts to dig out their repressed voices in fact implies her criticism of the amnesia the Canadians suffer from, and their blindness to what once happened in the country. In addition, it can also be understood as Atwood's attempt to unite the "self" and the "other": just as Iris blends together with her "other", Laura, to form a unified "self" and write their shared past with left hands, the Canadians are only able to stride over the colonial mentality to reconstruct their national identity by recognizing and accepting their unofficial and unpopular history. Similar ideas can be found in the science fiction about the blind assassin and the sacrificial girls, through which Atwood reinforces a critical reflection on Canada's past. Apart from revealing the experience of underprivileged, she also forecasts the possible solidarity between these groups, or even the whole society - the alliance between Canada's "self" and its internal "other". She negotiates with the dead to bring back their stories, and to provide Canadians with a full picture of their history, and hence making it possible for them to get the clear knowledge of their "self", through which they can reconstruct their national identity to defend themselves against future external threats.

\section{References}

[1] McIntosh, Andrew. "Rebellions of 1837-38." The Canadian Encyclopedia, 15 July 2013, www.thecanadianencyclopedia.ca/en/article/rebellionsof-1837. Accessed 14 June 2021.

[2] McCullough, J. J. "20th Century History of Canada." Canada

Guide, www.thecanadaguide.com/history/the-21st-century. Accessed 14 June 2021.

[3] Atwood, Margaret. Second Words: Selected Critical Prose 1960-1982. House of Anansi P, 1982.

[4] ---. Alias Grace. Bantam Doubleday Dell Publishing Group, Inc. 2003.

[5] ---. "In Search of Alias Grace: On Writing Canadian Historical Fiction." American Historical Review.

[6] ---. The Blind Assassin. Random House. 2000.

[7] ---. Negotiating with the Dead. Virago P, 2003.

[8] ---. The Handmaid's Tale. Vintage Books. 2019.

[9] Spergel, Julie. "Constructing a Multicultural Identity at the Canadian Frontier: Mordecai Richler and Jewish-Canadian Writing." Views of Canadian Cultures. vol. III, no. 2. p. 141.
[10] Cooter, Roger. The Cultural Meaning of Popular Science. London: Cambridge University Press. 1984.

[11] Natioally Accredited College of Hypnotherapy. "The Birth of Mesmerism." Hypnosis Motivation Institute, www. hypnosis.edu/history/the-birth-of-mesmerism. Accessed 14 June 2021.

[12] Rogerson, Margaret. "Reading the Patchworks in Alias Grace." Journal of Commonwealth Literature, vol. 33, no. 1,1998 . p. 15

[13] Goldman, Marlene. "Memory, Diaspora, Hysteria: Margaret Atwood's Alias Grace". Memory and Migration: Multidisciplinary Approaches to Memory Studies, edited by Julia Creet and Andreas Kitzmann. U of Toronto P, 2011, p. 10.

[14] Michael, M. C. "Rethinking History as Patchwork: The Case of Atwood's Alias Grace." MFS Modern Fiction Studies, vol. 47, no. 2, 2001. p. 439.

[15] Hegel, G. W. F. Phenomenology of Spirit. Translated by A. V. Miller, Oxford U P, 1977.

[16] Howells, Coral A., editor. The Cambridge Companion to Margaret Atwood. Cambridge U P, 2006.

[17] Žižek, Slavoj. Looking Away: An Introduction to Jacques Lacan. The MIT P, 1992.

[18] Dino, Felluga. "Modules on Lacan: On the Gaze." Introductory Guide to Critical Theory, 17 July 2002, www.cla.purdue.edu/academic/english/theory/ psychoanalysis/lacangaze.html. Accessed 15 Nov. 2020.

[19] Zuern, John David. Lacan: "The Mirror Stage". CriticaLink, www.english.hawaii.edu/criticalink/lacan/guide6.html. Accessed 14 June 2021.

[20] Parker, Rozsika. The Subversive Stitch: Embroidery and the Making of the Feminine. The Women's Press Ltd, 1984.

[21] Bailly, Linoel. Lacan: A Beginner's Guide. Oneworld Publications, 2009.

[22] Klages, Mary. Literary Theory: A Guide for the Perplexed. Continuum International Publishing Group, 2006.

[23] Marx, Karl and Friedrich Engels. Communist Manifesto. Oxford U P, 1992.

[24] Staels, Hilde. "Atwood's Specular Narrative: The Blind Assassin”. English Studies, vol. 85, no. 2, 2004. p. 151.

[25] The Forgotten Camps; ABC News 20/20 Special Report -Hitler's “Master Race:” Nazi Program Attempted to Create Racially Pure Children (April 27, 2000).

[26] Renan, Ernest. What is a Nation? And Other Political Writings. Columbia U P., 2018.

[27] Evans, Dylan. An Introductory Dictionary of Lacanian Psychoanalysis. Routledge, 1996.

[28] Gounelas, R. P. "'What isn't there' in Margaret Atwood's The Blind Assassin: The Psychoanalysis of Duplicity." MFS Modern Fiction Studies, vol, 50, nol, 3, 2004. p. 692.

[29] Zhang, W. (2020). The "Bunker" of Physics and Psychology: The Customs of Visiting the Lunatic Asylum and the Paradigm of Canadian Literary Imagination. Foreign Literature Review, (02), 207-222

[30] Chen. G. X. Towards De-Imperialization: Asia as Method. Pedestrian Publishing House, 2006. 